\title{
Influence of Customer Relationship Marketing and Satisfaction of Customer Loyalty (Case Study: In Bank CIMB Niaga Lembong in Bandung)
}

\author{
Anny Nurbasari \\ Maranatha Cristian University, Bandung, Indonesia \\ Nisa Hanum Harani \\ Indonesia Polytechnic of Post, Bandung, Indonesia
}

\begin{abstract}
The purpose of this study was to examine the theoretical basis in an effort to build the competitiveness of the banking services industry, particularly in terms of customer satisfaction and loyalty. This type of research uses explanatory research. The sampling method used a non-probability sampling, used purposive sampling technique that has become a customer for two years, used questionnaires to 100 respondents in Bandung bank customers. Measurement validity uses confirmatory factor analysis, while test reliability is calculated by Cronbach Alpha method. Analysis to test the hypothesis uses the path analysis. The findings illustrate a clear pattern of the dimensions of customer relationship marketing, satisfaction effect built, and several important findings including empirical verification mediating role overall customer satisfaction in the formation of loyalty attributes.
\end{abstract}

Keywords: customer relationship marketing, satisfaction, customer loyalty

\section{Introduction}

The development of banking in the world of economy has now arrived at a situation of tight competition and challenges that must be faced by business operators in every sector of economic activity; consequently, this makes it difficult for banks to find loyal customers. Therefore, maintaining existing customers is an effort that is more relevant. Assessed from the cost perspective, it is more costly to get new customers compared to retaining customers (Kotler \& Keller, 2012).

Many banking companies begin to improve themselves by strengthening their strategy with various concepts, such as market oriented or customer focused culture to maintain their profitable access to the market and ensure a sustainable growth (Ferdinand, 2000). To meet the customer satisfaction, along with the increasingly rapid technological change as well as the challenges in global competition, effective marketing strategies are required to maintain the customer's loyalty. In order to successfully compete in the business environment which is constantly fluctuating, a reliable marketing strategy is oriented to the target marketing needed to bridge the customer's wants. However, in the implementation of its strategy, the company might

Anny Nurbasari, doctor of Philosophy, Maranatha Christian University, Bandung, Indonesia.

Nisa Hanum Harani, master of Science, Indonesia Polytechnic of Post, Bandung, Indonesia.

Correspondence concerning this article should be addressed to Anny Nurbasari, Kudus 12, Bandung 40291, Indonesia. 
experience a failure if not supported by the internal party of the company itself, as well as the external party; in this case the customers constantly demand satisfaction from the performance of the banking company (Prichard, Havitz, \& Howard, 1999).

In terms of creating customer satisfaction, the company is required to increase its value provided to customers (customer's value) in addition to benefits of its products (product advantage). Customer's value can be created through the delivery of superior service quality to its customers. The better the quality of service is delivered, the higher the level of customer satisfaction that is expected to affect the loyalty of its customers. Prichard et al. (1999) suggest that customer loyalty to the brand (brand loyalty) should be directly affected by customer satisfaction in the brand accumulated through time.

Research findings of Anderson, Fornell, and Lehmann (1994) find out that if the customer is satisfied with the products or services provided, it indicates the customer's loyalty that customers will make repeat purchases (repurchase) in the future, lower price elasticity, hinder a competitor, to attract customers because they are reluctant to switch (switching), lower the costs and time of future transactions, lower the costs of handling non-compliance of products/services, reduce costs, and find new customers. Moreover, customers will have the tendency to inform more to potential customers since the company has products and satisfactory services; as a result, the logical consequences of the company's reputation will improve.

One of the strategies undertaken by banks in improving the quality of service to consumers is to make the customers satisfied and loyal to implement customer relationship marketing through commitment airport, communication with customers, and handling customer complaints as a focus on building customer relationships (Ndubisi, 2003).

Loyalty is the result of good relations with customers in the long term. Running a business relationship-based approach is needed in order to obtain an understanding of what is needed and wanted by a customer and the customer is considered to be long-term assets (Barnes, 2003).

The reason of the development of research is to bridge the gap in the banking world that is constituted by: more sophisticated and knowledgeable customers, a dramatic change in technology, the emergence of competition, the failure of many commercial banks in the city to retain its customers. Customers who switch from one bank to another have caused a decrease in the number of repeat purchases. This is due to the failure to embrace a relationship with the customer. Without providing customer satisfaction, customer commercial banks will continue to defect from one bank to another and this has cost implications not only to customers, but also to the banks themselves (Caroline \& Elizabeth, 2014). This phenomenon is a challenge in the banking world, and it seems that there is no harmony in how to best satisfy customers and customer loyalty.

In a world of increasingly competitive global finance, customer relationship marketing is the best way for banks to build long-term relationships with their unique customers. Technological developments are changing very rapidly making it difficult to gain a strategic advantage over the physical product. At the same time, customers are more demanding; they not only expect high-quality goods or services, but also the availability of services as a requirement for their loyalty to the bank. Meanwhile, most of the core products/services in commercial banks are quite generic, and therefore it is difficult for most types of financial institutions to compete purely in these core services. As a result, the bank uses the concept of relationship marketing as a strategy to satisfy the customer to build loyalty with every customer, which leads to the improvement of financial performance and the market, and thus increases competitive advantages (Ravesteyn, 2005).

This study will provide some important contributions to fill the gap by identifying the extent of the 
influence on satisfaction of customer relationship marketing, relationship marketing influence on customer loyalty, and the effect of customer satisfaction on customer loyalty. Besides, it will expand the implementation of customer relationship marketing in developing countries, and particularly in the banking industry in Indonesia. The expected empirical findings from this study will be valuable information for understanding and enhancing customer confidence and satisfaction so that they will be loyal to the bank.

Customer relationship marketing is trying to build a more constructive relationship with targeted customers and choose to expand a long-term marketing success compared to only pursuing a target of public attention in a wider scale (Khoe, 1997). Customer relationship marketing is a marketing strategy exercised by the company with the objective to maintain and improve customer satisfaction through the customer values expected to provide benefits for customers and allow complicated barriers of competition for competitors, so that the company is able to increase customer loyalty (Evans \& Laskin, 1994; Hennig-Thurau \& Klee, 1997; Reynold \& Beatty, 1999).

\section{Literature Review}

Referring to Law No. 14/1967 in Chapter 1 concerning the main points of banking, a bank is defined as a financial institution which gives credits and services in the traffic of payments and the circulation of money. From the point of distribution, banks are not only trying to capture as many profits as possible for the owner, but also to be directed at improving the living standard of the community (Siamat, 2005).

\section{Relationship Marketing and Customer Loyalty}

The basic philosophies of relationship marketing are based on the assumption that company-customer interactions and strategies can earn and keep the loyalty of customers (Berry, 1995). Gummesson (1994) defines relationship marketing as a continuation of the mutual relationship between a service provider and a customer who will lead to the formation of profitability. Therefore, banks, as the financial service providers, can retain profitable customers and increase their loyalty by planning in their marketing strategies (Kim, Park, \& Jeong, 2004).

The results of the study (Bagherzad, Chavosh, \& Hosseinikhah, 2011) confirm that a service company has received tremendous benefits from loyal customers. Moorman, Zaltman, and Deshpande (1992) state that customer loyalty is the intention to maintain valued relationships. Yim, Tse, and Chan (2008) define customer loyalty as a very deep commitment to continuing to purchase products or services in the future in spite of the fact that there are situational factors and marketing efforts have the potential for creating a switching behavior. In the banking sector, this is the main task of managers and marketers to create and develop customer loyalty if they want to maintain their company and increase profitability. Therefore, we have hypothesized the relationship between relationship marketing and customer loyalty as follows:

H1: Relationship marketing makes effect on customer loyalty.

\section{Relationship Marketing and Customer Satisfaction}

Doyle (2002) finds that three pillars of relationship marketing are the planning and controlling of customer satisfaction, building and maintaining stable relationships (customer loyalty), and customer value management. Kotler (2000) finds that customer satisfaction includes comparisons between the expected value delivered. Furthermore, Kotler, Armstrong, Saunders, and Wong (2001) conclude that customer satisfaction is highly dependent on the expectations of the customer and how the customer's actual perception of the performance of 
products is in line with the expectations. Customers will be satisfied if the performance matches or exceeds expectations, and vice versa, the customer is not satisfied if the performance does not match expectation. Previous research revealed that relationship marketing program improved the information flow between banks and customers and increased positive feelings towards their bank customers. Thus, it will increase customer satisfaction and strengthen bank relationships (Barnes \& Howlett, 1998; Ennew \& Binks, 1996). Therefore, based on the empirical findings, hypothesis 2 is proposed as follows:

$\mathrm{H} 2$ : Relationship marketing influences customer satisfaction.

\section{Customer Satisfaction and Loyalty}

The effect between satisfaction and loyalty has been widely investigated in several studies (Selnes, 1993). Fornell (1992) says that customer satisfaction affects the behavior of buyers, where satisfied customers will be loyal, yet loyal customers do not have to be satisfied. Loyalty indicates the company's ability to position their products in the minds of customers, in which the company tries to treat customers as partners by way of confirming the confidence of customers, and always interacts with them when they need to develop for the future progress (Kartajaya, 1999), while a loyal customer is someone who makes repeat purchases from the same company, notifies the other potential customers by word of mouth, and becomes a shield attack from competitors (Evans \& Laskin, 1994). Therefore, it can be said that the indicator for the success of a company is determined by customer loyalty.

They have found out that highly satisfied customers tend to stick to the current service provider. Yet, many studies have shown that customer satisfaction, despite a positive effect on customer loyalty, is not always a prerequisite for the effect on the level of loyalty, and the concept of switching barrier (barrier switch) as proposed (Jones, Mothersbaugh, \& Betty, 2003). Barriers shift plays the role of an adjustment variable in the relationship between customer satisfaction and customer loyalty. In other words, when a level of customer satisfaction is detected, customer loyalty levels can vary depending on the strong barriers to switching (Cogate \& Lang, 2001; Jones et al., 2003; Lee \& Cunningham, 2001). The significance of customer loyalty is closely linked to the survival of the company and the company's continuous strong growth. Therefore, in order for the company to maintain stable profit levels, the market should reach a mature age or maturity in very keen business competition. Strategies to retain customers are far more important than aggressive strategies, such as expanding the size of the market to hook potential customers (Fornell, 1992; Ahmad \& Buttle, 2002).

Customer loyalty also means loyalty of customers to be willing to shop at a particular location of a company (Utami, 2006, p. 58). Customer loyalty is known as a significant factor in a successful business. Therefore, it can be said that the success of customer loyalty in business organizations is significantly more important than customer satisfaction (Taleghani, Chirani, \& Mirrashed, 2011, p. 2022).

Therefore, based on empirical findings, hypotheses 3 is proposed as follows:

H3: Satisfaction makes effect on loyalty.

\section{Research Design}

The study population is all consumers of CIMB Niaga in Bandung, so the unit of analysis is the consumers of CIMB Niaga. This type of research used in this research is explanatory research. Data are collected by using a questionnaire. This research is conducted at CIMB Niaga customers in Bandung and the number of samples is 100 samples with sample criteria that the customers' minimum age is 17 years old who are customers of CIMB 
Niaga for more than one year, have done more than six times of banking transactions in the past six months. Samples are selected by non-probability sampling method, using purposive sampling technique. The sampling approach is of Slovin with an error rate of $10 \%$, measurement validity using confirmatory factor analysis (CFA), test reliability is calculated by using Cronbach alpha. The analysis to test the hypothesis of the influence of customer relationship is the marketing on customer loyalty, influence of customer relationship marketing on customer satisfaction, and the impact of customer satisfaction on loyalty uses path analysis.

\section{Variable Operationalization}

Customer Satisfaction $\left(\mathrm{Y}_{1}\right)$ is measured through trust of customers, customer proximity, service assurance and satisfaction with the overall service quality; Customer Loyalty $\left(\mathrm{Y}_{2}\right)$, is measured by attitude selecting products despite rising transaction costs, repeat purchases, recommendation to others, and resistant to a competitor's product; Relationship Marketing (X) is measured by: commitments, communications, handling conflict.

\section{Measurement Variable}

In this study, the quantitative data analysis used is Likert scale, on a five (5)-point from one (1) - Strongly Disagree to five (5) - Vigorously Agree.

\section{Empirical Result}

\section{Testing of Research Instrument}

Testing of Research Instrument by looking at the Validity Test, and the Reliability Test, Measurement of quantitative validity uses Confirmatory Factor Analysis (CFA), the results are as follows:

Table 1

KMO and Bartlett's Final Test

\begin{tabular}{lll}
\hline Kaiser-Meyer-Olkin measure of sampling & & \\
\hline Adequacy & & 0.789 \\
Bartlett's test of sphericity & Approx. chi-square & $1,686.977$ \\
& df & 362 \\
& Sig. & 0.001 \\
\hline
\end{tabular}

Based on Table 1 above, it can be concluded that the level of intercorrelation between variables already qualified and factor analysis can be continued as the value of KMO generated amounts to 0.789 with 0.001 significant level $(\leq 0.05)$.

Based on the End Rotated Component Matrix, it can be concluded that the indicator of customer relationship marketing and customer satisfaction $(\mathrm{X})$ as well as the indicator of loyalty $(\mathrm{Y})$ is valid.

\section{Reliability Test}

Reliability test is done by using Cronbach Alpha method. The result is as follows.

Reliability test results with test Cronbach alpha $(\alpha)$ in this study indicate that all variables of the study are reliable, since the entire value of the alpha coefficient of each study variable is greater than the standardized (0.6), so that each item on the question measurement instruments can be used. 
Table 2

Summary of Reliability Test Results

\begin{tabular}{llll}
\hline Variable & Coefisien alpha $(\alpha)$ & Standart alpha & Conclusion \\
\hline Customer relationship & & & \\
\hline X1.1 & 0.767 & 0.60 & Reliable \\
X1.2 & 0.893 & 0.60 & Reliable \\
X1.3 & 0.823 & 0.60 & Reliable \\
\hline Customer satisfaction & & & \\
\hline X2.1 & 0.750 & 0.60 & Reliable \\
X2.2 & 0.781 & 0.60 & Reliable \\
X2.3 & 0.630 & 0.60 & Reliable \\
X2.4 & 0.807 & 0.60 & Reliable \\
X2.5 & 0.613 & 0.60 & Reliable \\
\hline Customer loyalty & & & Reliable \\
Y1 & 0.689 & 0.60 & Reliable \\
Y2 & 0.775 & 0.60 & Reliable \\
Y3 & 0.615 & 0.60 & Reliable \\
Y4 & 0.614 & 0.60 & \\
\hline
\end{tabular}

\section{Hypothesis Testing Results}

Hypothesis testing uses path analysis, and the overall test results can be seen in Table 3. Summary of results of testing path analysis can be explained as follows:

Table 3

Summary Test Results Path Analysis

\begin{tabular}{llllll}
\hline Exogen variable & Endogen variable & Standardized coefficient beta & $t$ value & Sig. & Information \\
\hline Relationship marketing & Customer satisfaction & 0.567 & 4.056 & 0.000 & Sig. \\
Relationship marketing & Customer loyalty & 0.718 & 7.930 & 0.000 & Sig. \\
Customer satisfaction & Customer loyalty & 0.486 & 4.233 & 0.000 & Sig. \\
\hline
\end{tabular}

Source: Researcher 2016.

$$
\begin{aligned}
\text { Indirect Effect: IE } & =\mathrm{PY}_{1} \mathrm{X} \times \mathrm{PY}_{2} \mathrm{Y}_{1} \\
& =0.567 \times 0.486 \\
& =0.275562
\end{aligned}
$$

The calculations show that the indirect effect of 0.275562 gets the results. These findings indicate that effect of relationship marketing on customer loyalty through customer satisfaction is by 0.275562 . It shows hat customer satisfaction variables play a role as an intermediary in the relationship marketing on customer loyalty.

$$
\begin{aligned}
\text { Total Effect: } \mathrm{TE} & =\mathrm{PY}_{2} \mathrm{X}+\mathrm{PY}_{1} \mathrm{X} \times \mathrm{PY}_{2} \mathrm{Y}_{1} \\
& =0.718+0.567 \times 0.486 \\
& =0.718+0.275562 \\
& =0.993562
\end{aligned}
$$

The net effect is obtained by 0.993562 . This suggests that the effect of relationship marketing on customer loyalty mediated by customer satisfaction is by 0.993562 . It can be concluded that customer satisfaction variables are needed to strengthen the presence of the variable relationship marketing and customer loyalty. 


$$
\begin{aligned}
& \text { Appropriateness Model: } \\
& \begin{aligned}
\mathrm{R}^{2} & =1-\left(1-\mathrm{R}_{1}^{2}\right)\left(1-\mathrm{R}_{2}^{2}\right) \\
& =1-(1-0.321489)(1-0.515324) \\
& =1-(0.6785117)(0.484476) \\
& =0.539623 \text { or fifty-four percent }(54 \%)
\end{aligned}
\end{aligned}
$$

The result of the calculation model accuracy is by fifty-four percent (54\%), which suggests that the contribution of the structural model to describe the relationship of the three variables studied is fifty-four percent $(54 \%)$ and the balance of forty-six percent $(46 \%)$ is explained by other variables not included in this research model.

\section{Discussion and Implications}

\section{Effect of Relationship Marketing on Customer Loyalty}

The first hypothesis testing results show that the variable relationship marketing has a significant influence on customer loyalty variables. In line with the results of research conducted by Silmi (2012), it shows that the relationship marketing has a positive influence significantly on customer loyalty. RM implementation in CIMB Niaga has the main goal to build and maintain relationships with customers on an ongoing basis. Therefore, basically this implementation will lead to the means to create and maintain a strong attachment of the customers themselves to the marketers (Too, Souchon, \& Thirkell, 2000).

However, for customers, the implementation of RM conducted by marketers is a matter that will be perceived as an attempt for marketers to create and maintain good relations. Subjective perception of customers is what really determines the customer commitment. Implementation of RM conducted and perceived by marketers is not necessarily the same perceived by customers. By building relationships with customers, an organization can also get quality source of marketing intelligence for better planning of marketing strategies (Ndubisi, 2003).

It can be concluded that the marketing relationship is an effort to establish relationships in the long term and continuously with the customer, by involving the customer in producing the products offered by co-created experiences that lead to the collaborative marketing. Customer involvement in providing products or better services is to contribute ideas to improve the products offered by the bank that will become a marketing model at present.

\section{Effect of Relationship Marketing on Customer Satisfaction}

In this study, the hypothesis testing results to the two indicate that the variable relationship marketing has a significant influence on customer satisfaction variables. It can be concluded that better relationship forge will further improve the satisfaction of its customers. Customer satisfaction leads to profitability. If the quality of CIMB Niaga increases, customer satisfaction will increase too. According to Tjahyadi (2010, p. 2), satisfied customer will create a strong relationship and lead to customer loyalty. Customer satisfaction is dynamic and constantly updated with new product/service, new service, and communication that are more oriented to the customer and the customer relationship. These results are consistent with research conducted by Sutanto and Japarianto (2013), which show that the relationship marketing has a positive and significant influence on giving satisfaction to customers. Relationship marketing aims to build a satisfactory relationship with the company in the long term. Satisfaction created by the various services provided and the performance of these service providers 
create more value for the company. Many benefits can be felt by the company if it can create a customer satisfaction; for example, the creation of the relationship between the company and customers to be harmonious, customer loyalty, and form a recommendation by word of mouth that is profitable for the company.

\section{Effect of Customer Satisfaction to Customer Loyalty}

Results of testing the hypothesis third path analysis show that customer satisfaction has a significant impact on customer loyalty. It can be concluded that customer satisfaction is able to attract customers to become loyal. Customers who have been loyal to the company will be doing things that benefit the company. These results are consistent with a research conducted by Akbar and Parvez (2009) which show that there is a positive and significant influence between customer satisfaction and loyalty. Loyalty shown by its customers is the effect of the satisfaction they obtain.

In the long term, customer loyalty becomes a destination for strategic market planning, and it becomes the basis of competetive and sustainable development. Customer loyalty is an asset to the bank, which shows the high cost of loyalty, because building it faces a lot of challenges and it requires a very long time. This is a challenge that is not light for CIMB Niaga, considering that changes can occur at any time, either a change in customers, such as tastes and psychological aspects or aspects of environmental and social changes. Even though customer loyalty is the ultimate goal, there is no guarantee that the company can be lasting by itself, because companies should always actively seek innovations in response to any changes in customer behavior, the company, and competitors.

Loyal customers will ensure the sustainability of the company's life. As indicated in previous findings, bank customers who have a trusting relationship with their financial institution are more important than getting the best value for money (K. S. Coulter \& R. A. Coulter, 2003). In other words, satisfaction is a key driver to customer loyalty, to meet the more-than-expected customers optimally. Facts show that customers today are very smart, sophisticated, and assertive: they are no longer interested in buying solutions off-the-shelf, but they demand on a solution in accordance with the plan of their business model. Therefore, it is very important for banks to have strong relationships with their customers. This is because investment in loyalty can make a profit that is more interesting than launching an ambitious new marketing plan or building an additional branch in the location of the new location.

\section{Conclusion}

This paper discusses the relationship between marketing and customer loyalty in retail banks, using customer satisfaction as an intervening variable. This study confirms that the customer-centered marketing relationships directly affect customer loyalty. Combined indirectly effect of relationship marketing on customer loyalty is greater through customer satisfaction rather than directly. According to Shoemaker and Lewis in Tjahyadi (2010, p. 2), satisfaction can be hard without the loyalty and hard to have a loyalty without satisfaction. This study reaffirms the importance of customer loyalty. In the banking industry, it is important to optimize the use of technology, to analyze internal customer data and how they deliver information to their customers. Therefore, banks should use reports and customer complaints as a result of the focus on relationship marketing. The best and competitive way to forward must be rooted in strong customer relationships and customer loyalty at the heart of their growth strategies.

\section{Recommendations}


Based on the research, the implications of the research that can be developed are:

(1) CIMB Niaga always gives priority to develop culturally specific solutions to help customers, to understand exactly what the customer needs and focus on building relationships with customers with a sincere heart, intimate, and lasting relationships.

(2) Identify and determine the source of the problem that causes customers to complain and be dissatisfied, provide total solutions root cause of the problem.

(3) The study of the influence of relations marketing and customer satisfaction on customer loyalty is more comprehensive, so for further research, it is adviceable to consider the inclusion of variable marketing mix, attitudes, cultural values, life style, and motivation.

\section{Limitations of the Study and Areas for Further Research}

This study concentrates on the actual external customers who are customers of the bank for a long time that could have a different result if internal customers and potential are also involved in the study. Also, there is undue secrecy by the bank management to think that doing research in space of their banks has a negative impact on their customers. Additional research needs to focus on providing a greater understanding of the predecessor of the process of customer relationship marketing. For example, the study examines how organizations can bring "value" to the relationship and prevent turnover. Variables such as the volatility of the environment and the organization should be considered. Finally, additional research needs to focus on internal customer relationship marketing and its influence on customer loyalty.

\section{References}

Ahmad, R., \& Buttle, F. (2001). Customer retention management: A reflection on theory and practice. Jakarta: PT Gramedia Pustaka Utama.

Anderson, E. W., Fornell, C., \& Lehmann, D. R. (1994). Customer satisfaction, market share, and profitability: Findings from Sweden. Journal of Marketing, 58, 53-66.

Akbar, M, M., \& Parvez, N. (2009). Impact of service quality, trust, and customer satisfaction on customer loyalty. ABAC Journal, 29(1), 24-38.

Bagherzad, A., Chavosh, A., \& Hosseinikhah, S. (2011). The influence of relationship marketing tactics on customer's loyalty in B2C relationship-The role of communication and personalization. European Journal of Economics, Finance and Administrative Sciences, 5(31), 49-56.

Barnes, J. G. (2003). Secret of customer relationship management. Yogyakarta: Andi.

Barnes, J. G., \& Howlett, D. M. (1998). Predictors of equity in relationships between financial services providers and retail customers. International Journal of Bank Marketing, 16(1), 15-23.

Berry, L. L. (1995). Relationship marketing of service: Growing interest, emerging perspectives. Journal of the Academy of Marketing Science, 23(Fall), 246-251.

Caroline, M., \& Elizabeth, M. (2014). Determinants of customer retention in commercial banks in Tanzania. Journal of Finance and Bank Management, 2(1), 9-30.

Colgate, M., \& Lang, B. (2001). Switching barriers in consumer markets: An investigation of the financial service industry. Journal of Consumer Marketing, 18(4), 323-347.

Coulter, K. S., \& Coulter, R. A. (2003). The effects of industry knowledge on the development of trust in service relationships. International Journal of Research in Marketing, 20(1), 31-43.

Doyle, P. (2002). Marketing management and strategy (3rd ed.). London: Prentice Hall International.

Dick, A. S., \& Kunal, B. (1994). Customer loyalty: Toward an integrated conceptual framework. Journal of the Academy of Marketing Science, 22, 99-113.

Ennew, C, T., \& Binks, M. R. (1996). The impact of service quality and service relationship characteristics on customer retention: Small business and their banks in the UK. British Journal of Management, 7(3), 219-230. 
Evans, J. R., \& Laskin, R. L. (1994). The relationship marketing process: A conceptualization and application. Industrial Marketing Management, 23, 439-452.

Fornell, C. (1992). A national customer satisfaction barometer: The Swedish experience. Journal of Marketing, 60, 7-17.

Ferdinand, A. T. (2000). Manajemen Pemasaran: Sebuah Pendekatan Strategik. Semarang: Program MM UNDIP.

Gummesson, E. (1994). Making relationship marketing operational. Service Industry Management, 5(5), 5-20.

Hennig-Thurau, T., \& Klee, A. (1997). The impact of customer satisfaction and relationship quality on customer retention: A critical reassessment and model development. Psychology and Marketing, 14(8).

Jones, M. A., Mothersbaugh, D. L., \& Beatty, S. E. (2003). The effect of locational convenience on customer repurchase intention across service types. Journal of Services Marketing, 17(2), 185-201.

Kartajaya, H. (1999). Marketing plus 2000: Siasat memenangkan persaingan global. Jakarta: PT. Gramedia.

Kim, M. K., Park, M. C., \& Jeong, D. H. (2004). The effects of customer satisfaction and switching barrier on customer in Korean mobile telecommunication services. Telecommunications Policy, 28, 145-159.

Kotler, P. (2000). Marketing management. New Jersey: Upper Saddle River.

Kotler, P., Armstrong, G., Saunders, J., \& Wong, V. (2001). Principles of marketing. Harlow: Prentice Hall Europe.

Kotler, P., \& Keller, K. L. (2012). Marketing management (14th ed.). New Jersey: Pearson Education, Inc.

Khoe, Y. T. (1997). Relationship marketing strategi kemampulabaan jangka panjang. Manajemen Usahawan Indonesia No. 03 Tahun XXVI Market, 6-10.

Lee, M., \& Cunningham, L. F. A. (2001). Cost/benefit approach to understanding service loyalty. Journal of Services Marketing.

Moorman, C., Zaltman, G., \& Deshpande, R. (1992). Relationships between providers and users of market research: The dynamics of trust within and between organizations. Journal of Marketing Research, 29(3), 314-329.

Ndubisi, N. O. (2003). Cultural dimension and relationship marketing: An African marketing model. Journal of Cultural Studies, 5(2), 214-241.

Paper Serie. No. 01 Program Magister Manajemen Universitas Diponegoro.

Prichard, M, P., Havitz, M. E., \& Howard, D. R. (1999). Analyzing the commitment-loyalty link in service contexts. Journal of the Academy of Marketing Science, 27(3), 333-348.

Reynolds, K. E., \& Beatty, S. E. (1999). Customer benefits and company consequences of customer-salesperson relationship in retailing. Journal of Retailing, 75(1), 11-32.

Ravesteyn, J. V. (2005). The effect of relationship banking on customer loyalty in the retail business banking industry. Thesis, Graduate School of Business Leadership, University of South Africa.

Selnes, F. (1993). An examination of the effect of product performance on brand reputation, satisfaction and loyalty. European Journal of Marketing, 27(9), 19-35.

Silmi, S. (2012). Persepsi Nasabah Tentang Relationship Marketing dan Pengaruhnya Terhadap Loyalitas (Studi Pada Nasabah Tabungan Utama PT. Bank Mega Syariah Cabang Malang). Jurnal Manajemen Pemasaran, 8(1), 1-14.

Siamat, D. (2005). Manajemen Lembaga Keuangan Kebijakan Moneter dan Perbankan (5th ed.). Jakarta: Lembaga Penerbit Fakultas Ekonomi Universitas Indonesia.

Sutanto. P., \& dan Japarianto, E. (2013). Analisa Pengaruh Service Quality, Price dan Customer Relationship Terhadap Customer Loyality dengan Customer Satisfaction Sebagai Variabel Intervening di Rumah Makan Taman Handayani. Jurnal Manajemen Pemasaran, 1(2), 19.

Taleghani, M., Chirani, E., \& Mirrashed, S. A. (2011). A conceptuality approach to relationship marketing and customers loyalty to banks. Journal of Basic and Applied Scientific Research, 1(11), Iran: Islamic Azad University.

Tjahyadi, R. A. (2010). Membangun Hubungan Jangka Panjang Pelanggan melalui Relationship Marketing. Jurnal Manajemen Pemasaran, 1(2), 110.

Too, L. H., Souchon, A. L., \& Thirkell, P. C. (2000). Relationship marketing and customer loyalty in a retail setting: A dyadic exploration. Aston Bussiness School Research Institute, 1-36.

Utami, C. (2006). Manajemen Ritel Strategi dan Implementasi Ritel Modern. Jakarta: Penerbit Salemba Empat.

Yim, C. K., Tse, D. K., \& Chan, K. W. (2008). Strengthening customer loyalty through intimacy and passion: Roles of customer-Firm affection and customer—Staff relationships in services. Journal of Marketing Research, 45(6), 741-756. 